\title{
COP21 Policies And Abrupt Climate Change: Political Economy of Hawking's Irreversibility
}

\author{
Jan-Erik Lane
}

Professor emeritus at UNIGE, Switzerland janeklane@googlemail.com

\begin{abstract}
Climate and earth scientists have convinced a large majority of people that climate change occurs today. And the new theory of abrupt climate change entails that huge feedback lopes will change the Earth already within the next one or two decades. Yet, this information is only half the story, as the pragmatical side is also part of climate change: will the COP21 promise of global decarbonisation be fulfilled? It requires global coordination by states or government, which is very hard to achieve. The COP process by the UNFCCC and the IPCC never speaks about it. The aim of this paper is to emphasize that global deecarbonisation can only be accomplished by global state coordination, which reduces the probability of COP21 success considerably.

Keywords: elimination of coal and charcoal, solar power plants, carbon capture, abrupt climate change theory, methane spike
\end{abstract}

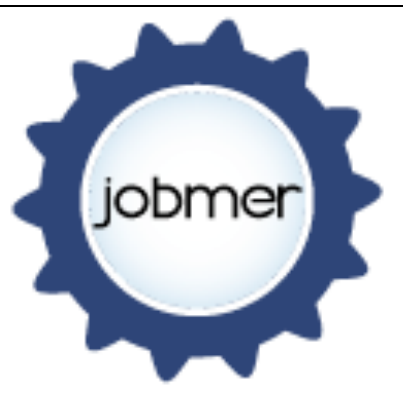

Journal of Business Management and Economic Research Vol.2, Issue.5, 2018 pp.1-19

Doi: $10.29226 /$ TR1001.2018.30 


\section{INTRODUCTION}

Global government coordination has come so far that the UN has enacted the policy objective of almost complete decarbonisation in this century at the COP21 reunion in Paris 2015. Bur how is this formidable objective to be managed? Can the increase in GHGs be stopped before the socalled Hawking irreversible point, where climate chaos become unstoppable? To ponder about the question, so fatal for humanity, we need a social or economic theory about the increase in GHGs. Why do people continue to increase these dangerous externalities?

Thus, far, the COP21 project involves a halt to the increase in CO2 emissions by 2020 , a $30 \%$ reduction in CO2s by 2030 (absolutely or relatively?) and more or less total decarbonisation by 2075. But the means to these gigantic goals? It is all about managing policies of energy transformation, as the augmentation of GHGs stems from human use of energy resources.

As we get more and more dire predictions about the nature of climate change and its probable consequences, it becomes more and more urgent to clarify what the COP project can and must accomplish. Climate change could be halted by a sharp reduction in the use of fossil fuels over night, but it would spell large scale economic crisis with mass unemployment and social upheaval.

Many climate experts now claim that we are heading for more than $a+2$ Celsius increase in global warming as well as already a +2 Celsius augmentation is a threat to human survival due to the many positive feedback loops started by such an increase. As the doomsday scenarios gather strength, it becomes absolutely vital to stick to the COP project and explore what can be achieved and how. It is a matter of Arctic ice meltdown and methane emissions from the permafrost that may bring temperatures much higher than the COP21 Treaty aimed at with uncertain disastrous consequences for both Mother Earth and mankind. Lots of natural science research still remains to be done in order to reduce the large uncertainties about temperature rise and its consequences for a number of vital outcomes for humanity, but it is now time for political and economic coordination to start global decarbonisation. Time is tight.

\section{POLICY IMPLEMENTATION ENTAILS MANAGEMENT}

Climate experts and earth scientists talk "abrupt climate change" as well as the "methane bomb", widening the set of GHGs to focus upon methane, emerging chaotically from the melting permafrost in the Northern most part of the hemisphere or from melting ice containing frozen methane at the seabed in the Arctic. The potential amount of methane to be released in the worst case scenario is so large that global warming would quickly move beyond the Hawking irreversible point, spelling doom for mankind. The time spam for the methane bomb is uncertain, from 50-200 years. What to do? At this point in time, global coordination against climate change can only intensify its efforts at decarbonisation during the $21^{\text {st }}$ century. The COP21 project has to be pursued and fulfilled in an improved version with quicker actions, complemented by other activities like carbon sequestration or Geo-engineering, if workable. Hopefully, the US will reenter this common pool regime later.

The overall objective of the COP21 project from Paris 2015 is to start decarbonisation by 2020 and finish it by 2075. A necessary condition is that states conduct energy policies that eliminate coal and start solar power parks. This requires enormous management skills by individual governments with huge support from global coordination agencies or committees. A drastic 
policy tool is carbon sequestration or capture, but it is hardly viable at the moment. Climate engineering may add to the basic means: abolition of coal and big solar power parks.

Theory: The basic hypothesis is the strong link between $\mathrm{CO} 2$ emissions and global temperature - Keeling' curve. Only by halting CO2 emissions first and then start reducing them can global warming be stopped and the methane bomb avoided. This is the foundation of the COP21 project and the possibility of geo-engineering may be an option as time goes by.

Implementors: The COP21 secretariat comprises some 450 persons, planning new global reunions, and monitoring the development of the country engagement for the Treaty as well as negotiating the promised reductions in $\mathrm{CO} 2 \mathrm{~s}$. It could be turned into a management agency assisting countries cut $\mathrm{CO} 2 \mathrm{~s}$ on the basis of interaction the Intergovernmental Panel for Climate Change (IPCC), working with concrete project implementation towards decarbonisation globally through the promised Super Fund.

Management tasks: Each country needs to develop a decarbonisation strategy, involving the crucial steps in the necessarily giant energy transformation from fossil fuels to renewables, given the most recent information available about energy and its presuppositions. The COP21 secretariat could be helpful in designing the best projects economically and come up with cheap international funding avenues, guaranteeing loans below market rates. It could make recommendation about carbon tax and renewable energy subsidies, mixing market and administrative steering mechanisms.

Competences: A reinforced COP21 developing into the management of global decarbonisation would act as an agency of first the UNFCCC and second as the agent of the principals of the $\mathrm{UN}$, viz. the member states. Its tools of management would be persuasion, oversight, recommendations, negotiations, but not authority or interference, given public international law. Yet, some control mechanisms would be necessary

\section{THE NEW CLIMATE DEBATE: “Already too late”}

Starting from the nature of public international law (PIL), the COP21 Treaty is based on voluntary emissions reductions, involving a COP secretariat with mostly information gathering tasks. The principle of state sovereignty permeates all of PIL The suggested speed of decarbonisation is slow: the COP21 policies involve $a$ halt to the increase in CO2 emissions by 2020, a 30\% reduction in CO2s by 2030 (absolutely or relatively?) and more or less total decarbonisation by 2075. But what are the means to these gigantic energy transformation goals? Basically, it is all about managing energy transformation, as the augmentation of GHGs stems from human use of energy resources.

Among some climate scientists, there is recently a new urgency. The melting of the North polar ice is advancing so quickly that all projections about temperature rise on the Earth must be revised upwards. Quicker warming sets in motion very positive feedback s that threaten human survival. The goal of COP21 - limit global warming to +2 degrees Celsius - is no longer achievable. Instead, climate chaos seems more likely. A few predict that mankind has no more than 10 years before things become unmanageable. When the North pole ice is gone, global warming goes much higher than +2 . 
The theory that climate change is now becoming irreversible is based on new hypotheses concerning the consequences of global warming:

- sea level rise and Arctic ice meltdown is quicker than believed;

- climate refugees may rise to 100 million people;

- food and water shortages come earlier than believed;

- the +2 degrees Celsius target is misplaced as the Earth warms differently at various regions, i.e. still much hotter at the poles;

- the release of methane from the permafrost and the frozen ice at the North pole will bring temperature rise to +10 degrees Celsius;

- the COP21 policy is too slow and uncertain.

As $\mathrm{CO} 2 \mathrm{~s}$ have risen too much since the industrial revolution, they must somehow be reduced in total. The COP strategy is to first halt the increase in $\mathrm{CO} 2 \mathrm{~s}$ and then reduce them, first by 30 per sent and later completely, which is of course Utopian. Abrupt climate change makes this strategy obsolete, because it is too slow and ineffective. Besides, it is ambiguous:

a) Yearly increase against total increase: the first goal of COP21 is to eliminate the yearly increases, but countries can still emit the sane amount CO2s. Since CO2s stay in the atmosphere for 100 years, total CO3s may still double up t0 2050.

b) Relative against total size of fossil fuels, especially coal: the big nations of the G20 plan for substantial augmentation of energy supply the coming decades; they will develop renewable energy and some of them atomic power plants, safer ones; so fossil fuel energy may be reduced relatively but sill remain much too high absolutely for decarbonisation.

c) No recognition of methane and feedback lopes: the COP21 project has no recognition of the spike in methane emissions in the Arctic and it bypasses the lethal threats to humanity from evolving feedback lopes changing thr climate and oceans for hundreds of years.

Now, we inquire below whether the key countries are moving or planning to move in this decarbonisation direction? Each single country has its energy consumption pattern that must be taken into account in both domestic and international energy supply transformation. Country resilience is important but it must be complemented by economic policy coordination, including the Super Fund.

\section{ENERGY AND ITS SOCIAL AND ECONOMIC IMPLICATIONS}

I suggest we analyse energy in a wide sense. The need for energy is obvious - see Figure 1. 


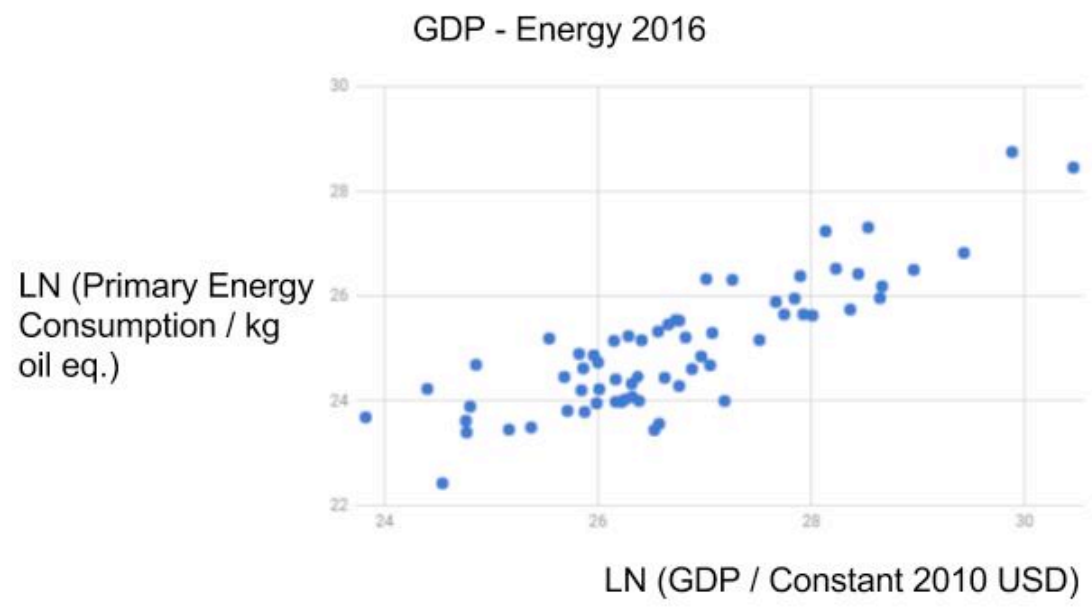

FIGURE 1. Energy and affluence globally

Energy is the capacity to do work. And work is the Adam Smith and J-B Say sources of human welfare. The growth in energy consumption since the industrial revolution and especially after the Second World War has been just immense, especially the supply of fossil fuels. In poor countries, the demand for energy is huge for economic development toward "catch-up", whereas rich countries are heavily dependent of fossil fuels for economic growth. The majority of countries in the COP project are in poverty, as they need more energy. Thus, they can only decarbonise when renewable energy sources become available. This is the redistribution task of C0P21: decarboisation against support for renewable energy by the Super Fund.

The living conditions in the poor countries in Latin America, Africa and Asia as well as the Pacific reflects the low level of energy employed. This basic fact determines life opportunities in a most dramatic fashion. The low access to energy has consequences for the environment and the life situation of people, including health, schooling, work, food and potable water.

For instance, African countries are poor because they have too little energy. Thus, they have much less GHGs than Asia. Yet, they need the COP project of the UNFCCC to renew their energy sources and move from fossil fuels and traditional renewables to solar power. Hydro power depends upon water availability that shrinks with global warming.

African energy deficit is conducive to a dire environment with enormous damages and risks. Consider the following global figures. Figure 2 shows how low energy leads to am unsafe environmental. 


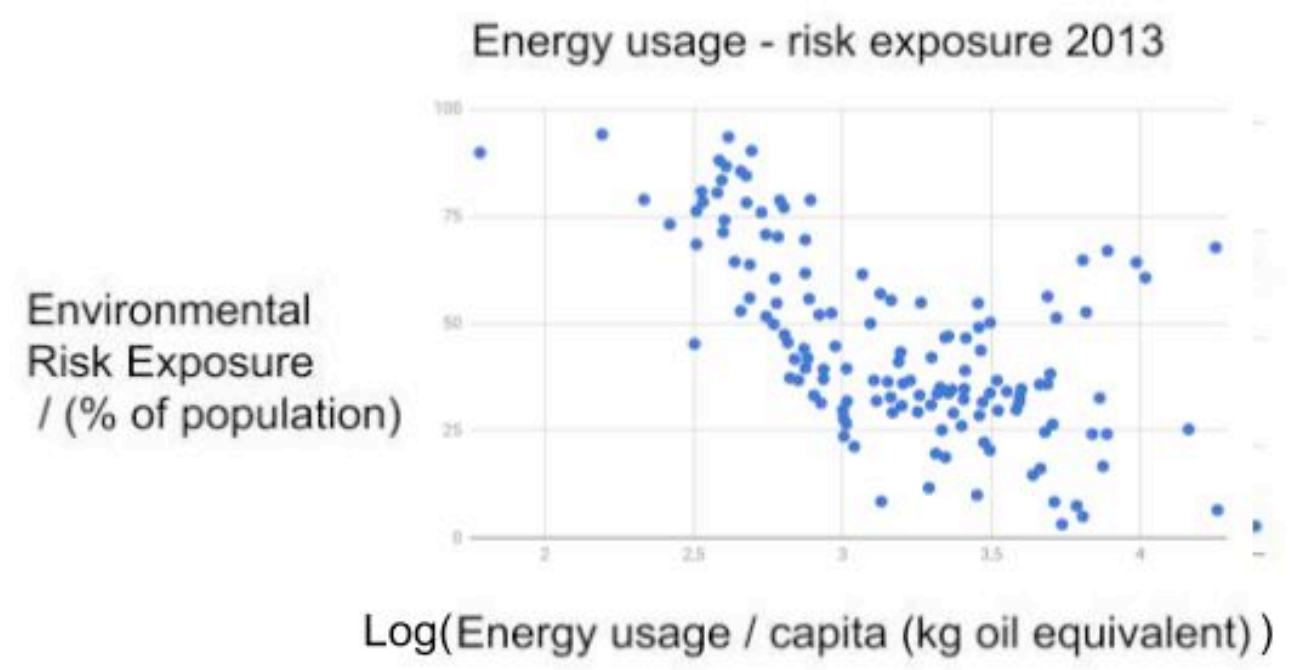

FIGURE 2: Energy and environmental risk exposure

Source: Environmental Performance Index, Yale University, https://epi.envirocenter.yale. IEA Statistics (C) OECD/IEA 2014 (http://www.iea.org/stats/inde

Low energy use leads to poverty, malnutrition, deceases, lack of potable water, insufficient sanitation, etc. Typical of many Latin American, African and Asian nations is the lack of stable electricity, which hampers everything and reduces environmental viability. Figure 3 has the global picture.

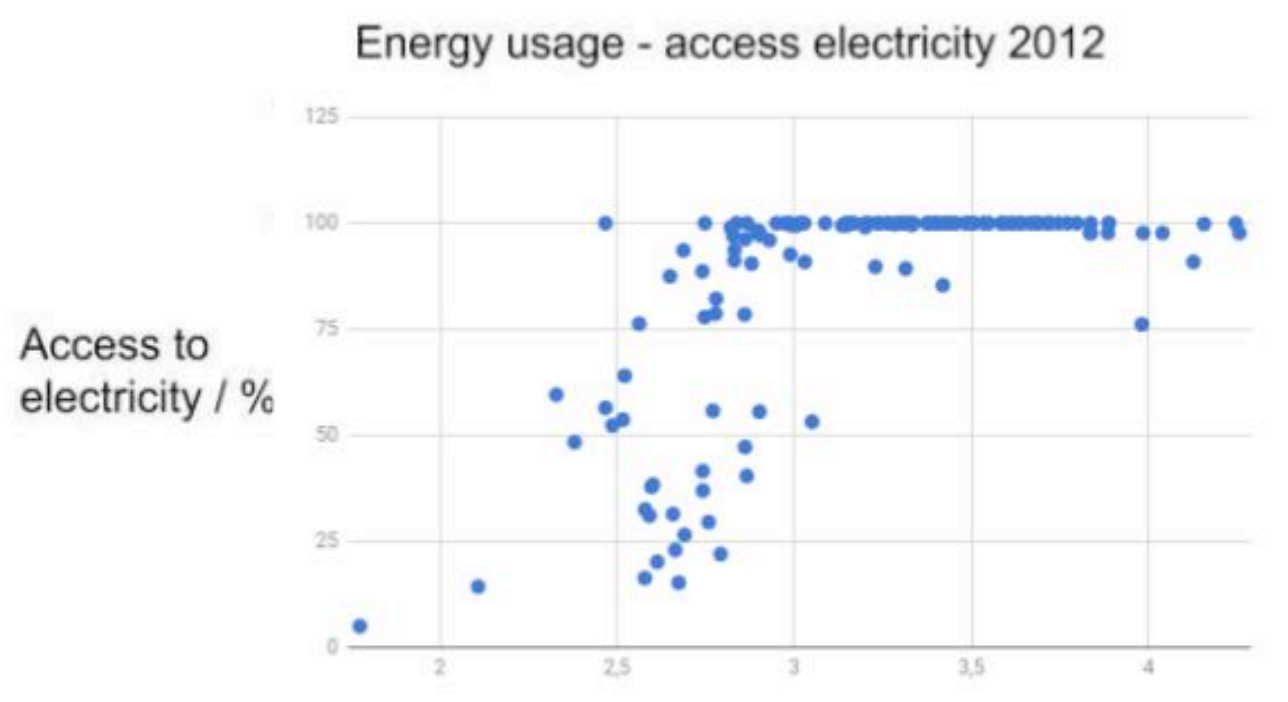

\section{Log(Energy usage / capita ( $\mathrm{kg}$ oil equivalent))}

FIGURE 3. Energy and electricity access

Source: Environmental Performance Index, Yale University, https:/epi.envirocenter.yale. IEA Statistics (C) OECD/IEA 2014 (http://www.iea.org/stats/inde

The access to safe and stable electricity is crucial for health, schools, food, water, etc. Figure 4 links energy with proper sanitation. 


\section{Energy usage - access sanitation 2014}

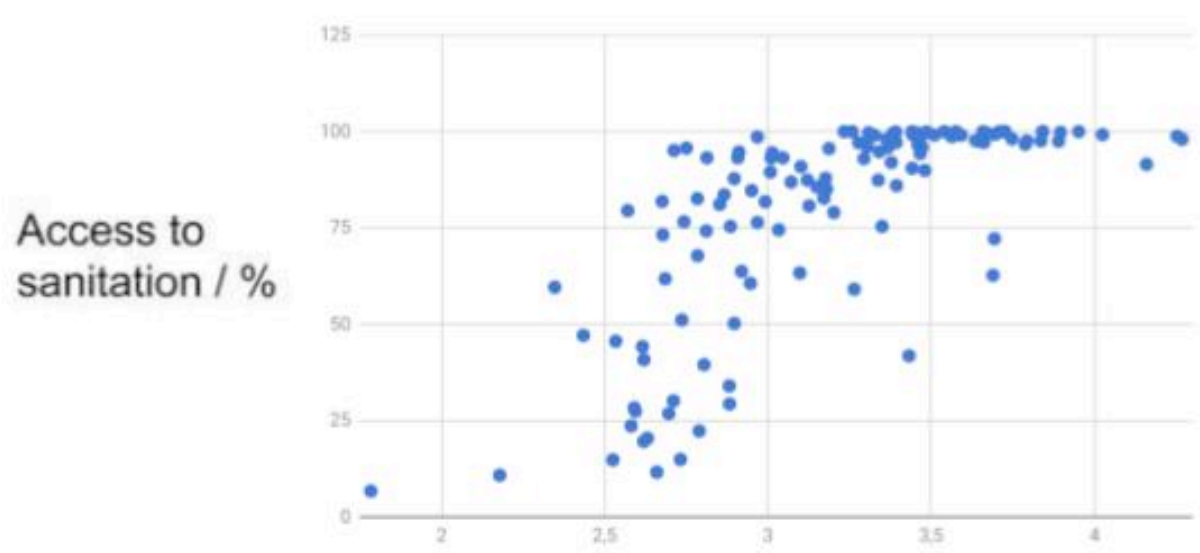

\section{Log(Energy usage / capita ( $\mathrm{kg}$ oil equivalent))}

FIGURE 4. Sanitation and energy

Source: Environmental Performance Index, Yale University, https://epi.envirocenter.yale. IEA Statistics @ OECD/IEA 2014 (http://www.iea.org/stats/index)

Especially, the rapidly growing African, Latn American and Asian mega-cities lack entirely proper sewage plants. Thus, dirty water is put into the big rivers where other cities downstream take their potable water.

The access to safe and stable electricity is crucial for health, schools, food, water, etc. Figure 4 links energy with proper sanitation.

\section{Energy usage - access sanitation 2014}

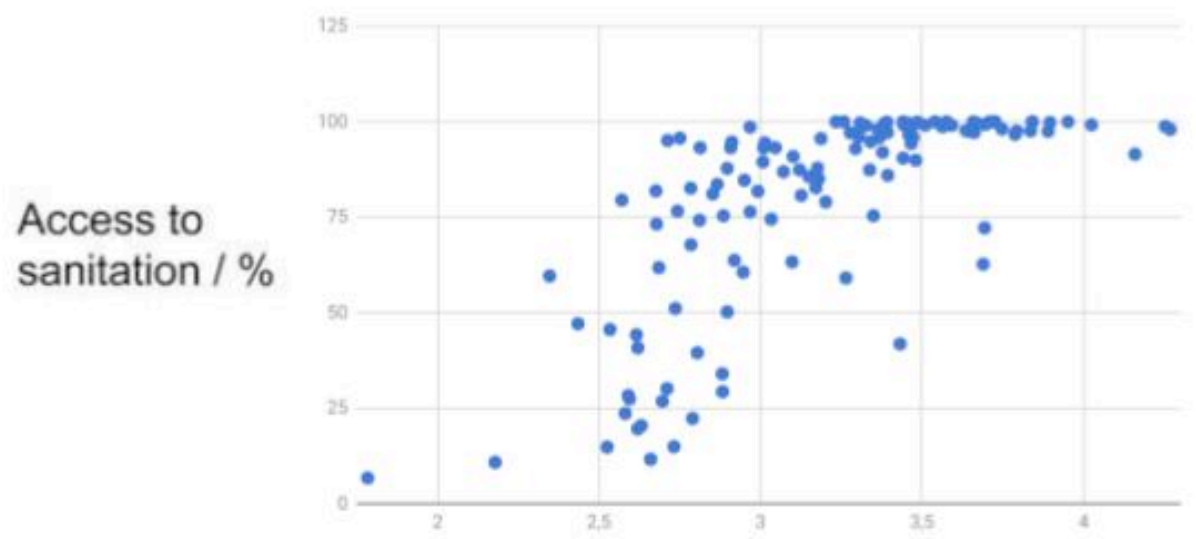

\section{Log(Energy usage / capita ( $\mathrm{kg}$ oil equivalent))}

FIGURE 4. Sanitation and energy

Source: Environmental Performance Index, Yale University, https://epi.envirocenter.yale. IEA Statistics () OECD/IEA 2014 (http://www.iea.org/stats/inde 
The necessity of more energy in poor coutries for prper sanitation, without which the life of humans is "salle", must be emphasized, especially when global warming diminishes clean water. Air quality too depends upon energy access (Figure 5(-

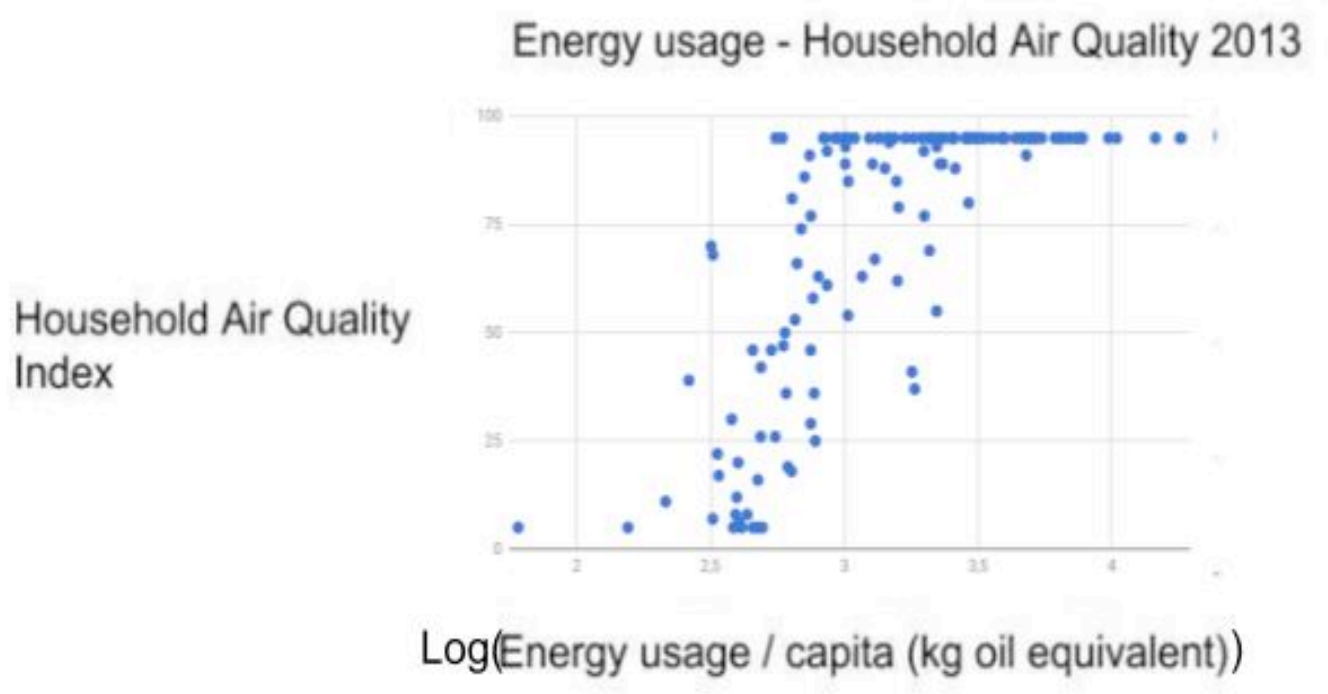

FIGURE 5. Energy and air quality

Source: Environmental Performance Index, Yale University, https://epi.envirocenter.yale. IEA Statistics @ OECD/IEA 2014 (http://www.iea.org/stats/inde

Typical of many poor nations - Latin America, Africa, Asia - is the lack of predictable access to safe electricity, which hampers work and reduces environmental viability. The access to safe electricity is, it must be emphasized, absolutely central for health, schools, food, potaable water, etc. Given the lack of enough energy in poor countries being conducive to the above bad living conditions, one understands the hopes of the poor countries for help with energy transformation leading to better access to just energy!

If, as we believe, energy consumption is behind global warming, the set of poor countries face a most difficult dilemma. On the one hand, they can demand much more energy like fossil fuels, but they then contribute much to climate change, On the other hand, global warming while fabricated by the rich nations and a few very populous poor nations, will have very negative consequences for poor nations. The only way out of this dilemma is that all countries contribute to halting global warming by turning to renewables, especially the set of rich countries.

Thus, energy consumption is closely related to country affluence. The poor countries can only improve living condition by increase energy supply. Their energy demand can only go up, because energy supply is highly skewed to the advantage of the rich countries - see Figure 6 . 


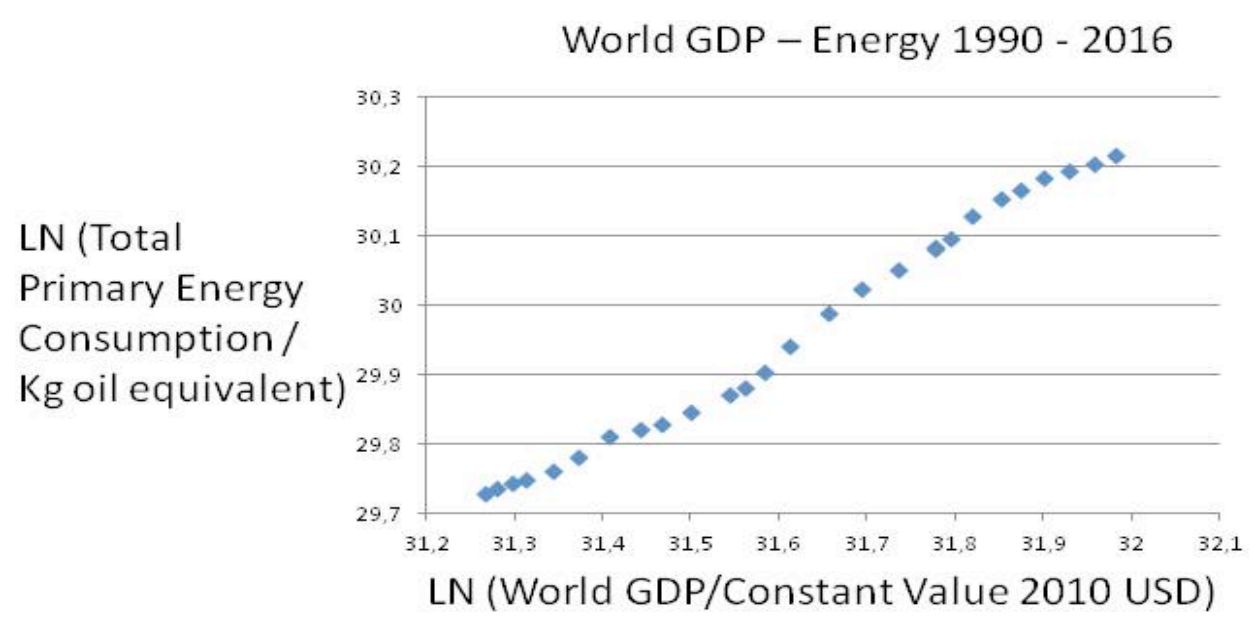

FIGURE 8. Global Energy Consumption 1990^- 2016

Poor countries need much more energy, but of a new kind. They need assistance to move to modern renewables, as they will give up fossil fuel only if there is compensation by other new energy sources. The enormous demand for more nd more of energy comes with a major drawback, namely the GHG emissions. Figure 7 has the picture for the CO2s.

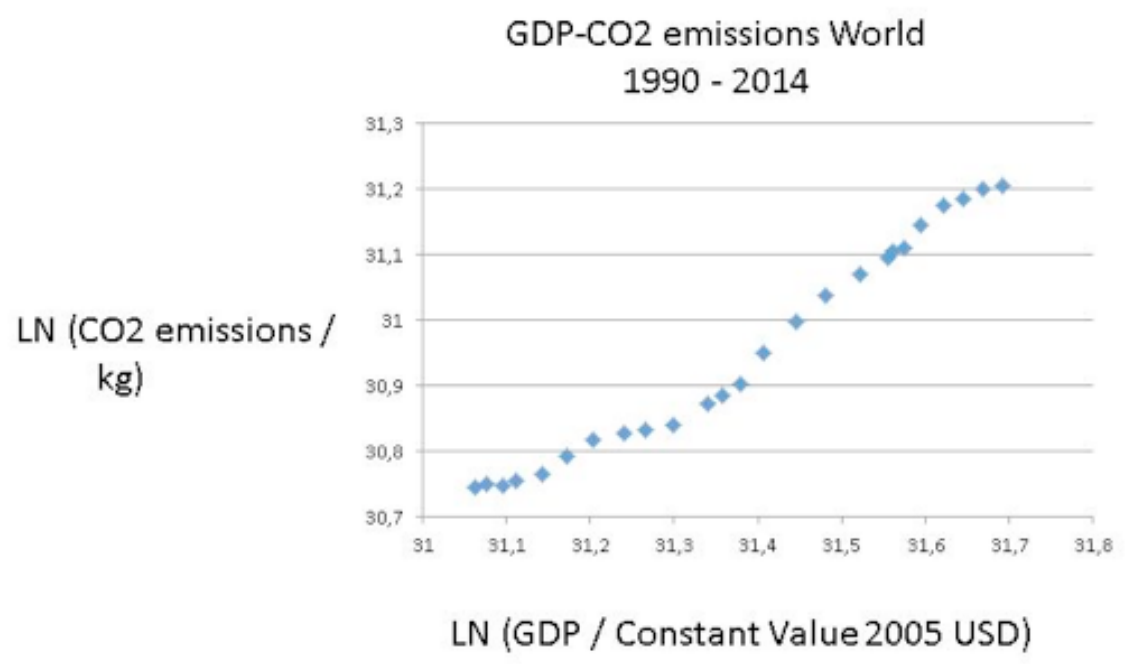

FIGURE 7. Energy and CO2s 1990-2016

It must be underlined that GHG emissions like $\mathrm{CO} 2 \mathrm{~s}$ are a function of GDP and population. Only very big poor countries have huge GHG emissions, like India, Brazil and Indonesia. Small poor nations have little GHGs, as they lack energy in great quantity. Yet, poor countries wish to participate in saving the planet from the dangers of climate change on the condition of financial assistance from the COP project and its Super Fund.

In terms of GHGs, rich countries have much higher levels of yearly emissions compared with poor countries, holding population constant. Only when a poor nation is huge, doe it have enormous CO2S.. Strict linear relation hold between GDP, energy consumption and GHGs, both on a per capita basis and on an aggregate country level. I will show one more picturee (Fguree 8) 
Energy usage - NO2 2011

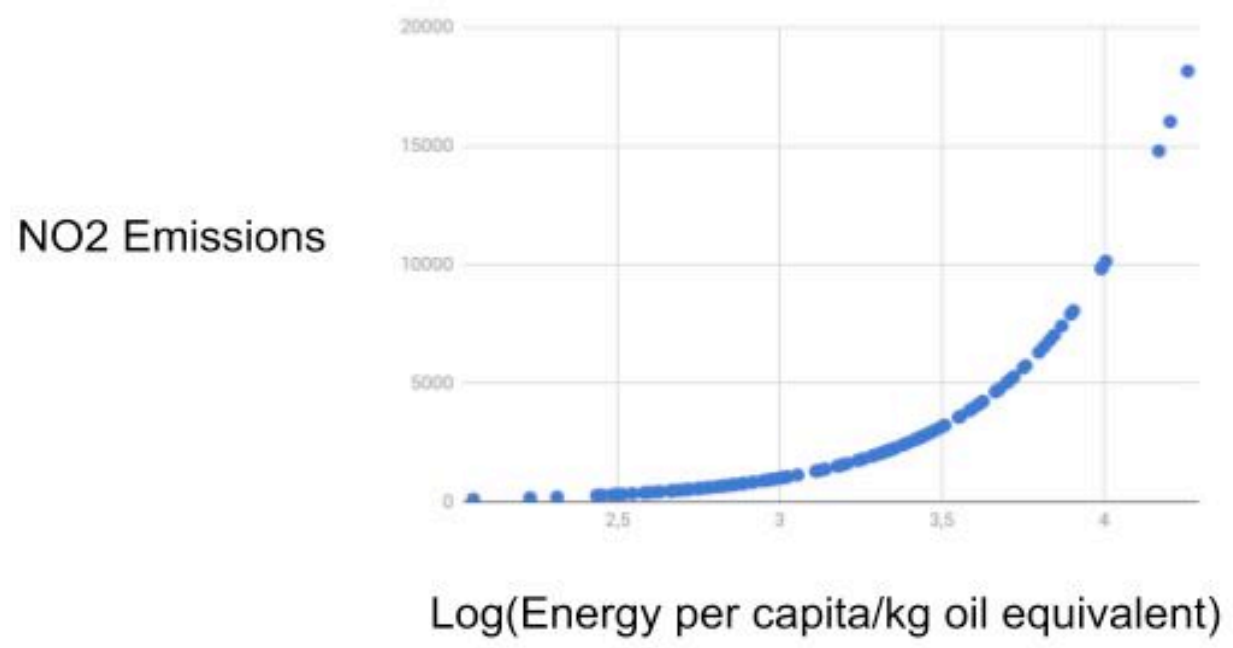

FIGURE 8. Nitrous oxide and energy

Source: Environmental Performance Index, Yale University, https://epi.envirocenter.yale. IEA Statistics @ OECD/IEA 2014 (http://www.iea.org/stats/inde)

While the UNFCCC has mainly concentrated upon the CO2s, the GHGs comprise several gases, on of which is the nitrogen oxide. Production of nitrous oxide stems from microbial activity in soils and in the ocean. Human sources of nitrous oxide are combustion of fossil fuels, biomass burning, industrial production of nitric acid, and fertilizers. Nitrous oxide enhances the greenhouse effect just as carbon dioxide does by capturing reradiated infrared radiation from the Earth's surface and subsequently warming the troposphere. It stays in the troposphere for about 120 years before moving into the stratosphere where it is conducive to the destruction of stratospheric ozone.

\section{COUNTRY MANAGEMENT IN LINE WITH COP21 GOALS?}

\section{India}

In Indian energy policies, it is emphasized that developmental goals take precedence over climate change considerations. Thus, all Indian household musst have access to electricity and only sustained rapid economic growth can reduce poverty. India has a "take-off" economy that delivers affluence for the first time since independence. But it is based on fossil fuels. India looks into other sources of energy, as long as socio-economic development is not hindered. Figure 9 shows the main features of future planning. 


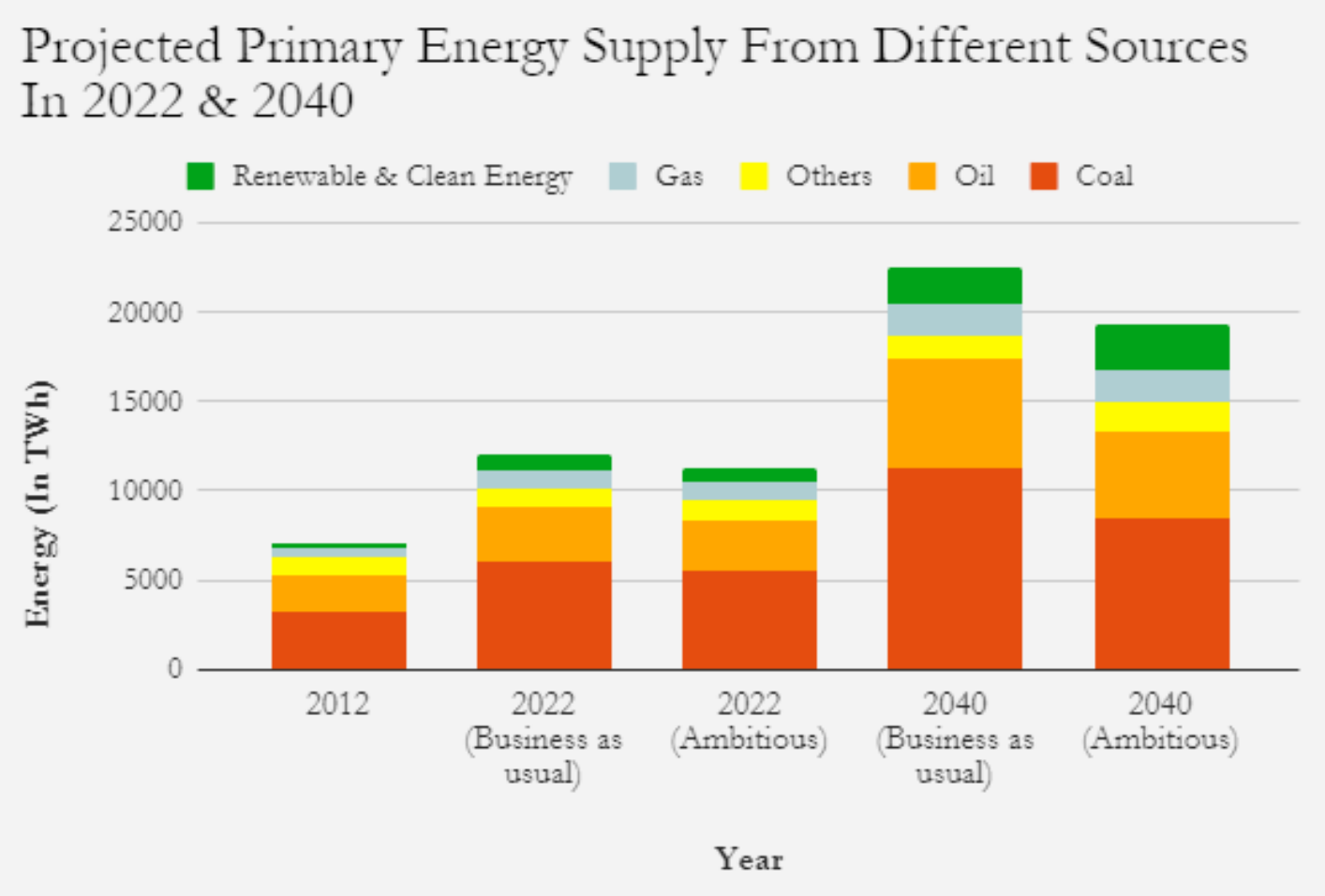

FIGURE 9. India`s energy future

Source:https://scroll.in/article/843981/indias-new-energy-policy-draft-projects-coal-firedcapacity-will-double-by-2040-is-that-feasible

India has rapidly become a major CO2 emitter due to its high growth rates since 1990. It uses lots of coal, stone or wood. Charcoal is bad for households and results in forest destruction. India tries to broaaden its energy supply to modern renewables, like solar, wind and hydro power. Yet, it will remain stuck with fossil fuels for decades. It needs assistance from the COP21 project, especially for solar power parks. Building more dams is very risky, as global warming reduces water assets. Figure 9 indicates the India cannot meet its COP21 promises, as Ramesh (2015) underlines.

\section{Brazil}

Brazil is a "catch-up" with its "take-off" point long ago in the $20^{\text {th }}$ century.. Compared with India, but it never really succeeds to close the gap to North America, tumbling now and then into dictatorship or recession. Figure 10 shows its stylised energy plans - are they in agreement with COP21 hopes of decarbonisaton? 


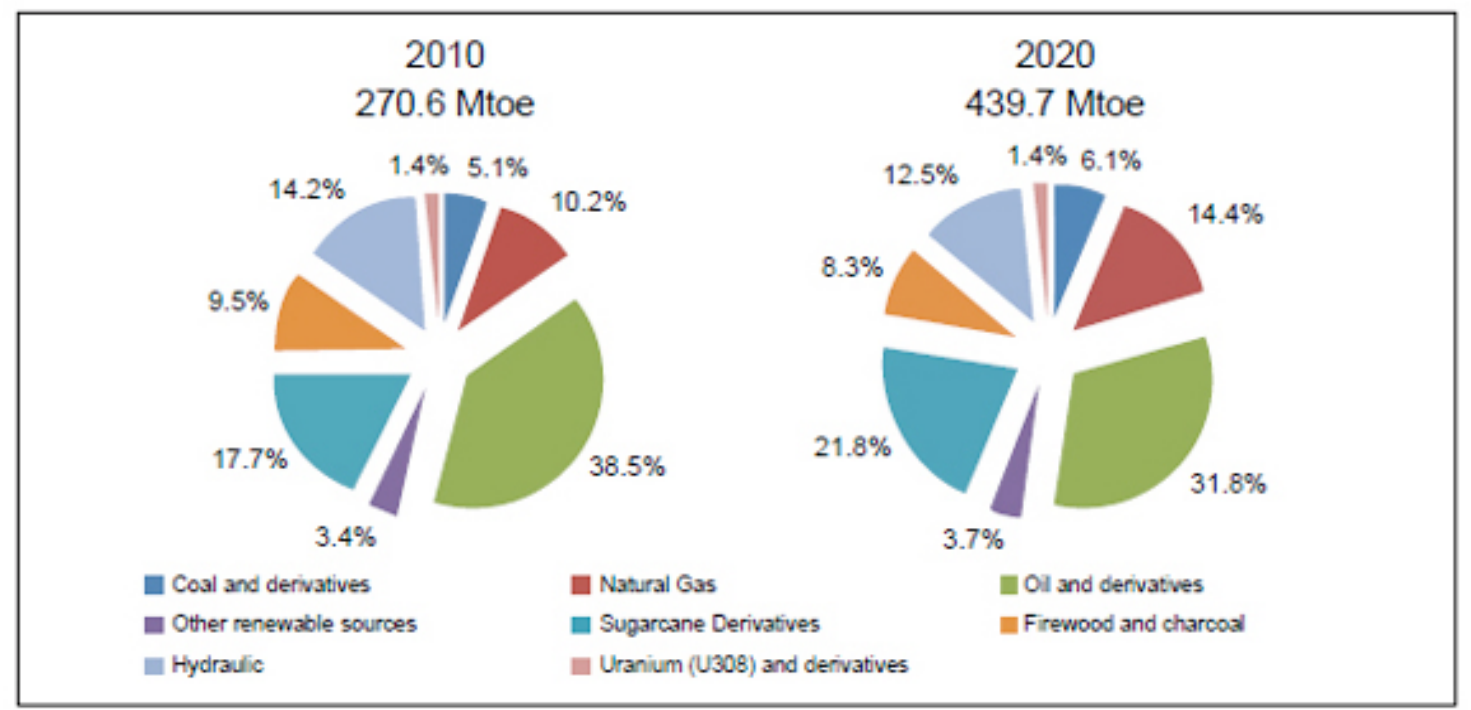

Figure1-Evolution of the total primary energy supply

FIGURE 10. Energy plans in Brazil

Source:http://www.scielo.br/scielo.php?pid=S0103-40142012000100017\&script=sci_arttext\&tlng=en

Brazil has already a diversified supply of energy. However, since the country plans to almost double its energy supply, its dependence upon fossil fuel will grow, also upon coal. It dreams about building many more dams in the Amazons, but future water shortages due to climate change may make these plans unrealistic. The country needs COP21 assistance to turn to solar power massively, in order to eliminate first and foremost coal and charcoal. The rain forest is part of Brazil' s emission picture where burning and logging reduce its carbon uptake.

\section{Indonesia}

Indonesia is like India a "takee-off" country, enjoying rapid economic growth with attending augmentation in energy consumption. The outcome is that this giant nation has quickly become a major GHG emitter. What make the situation worse is the burning down of the rain forest in parts of Indoneasia.

Such a phenomenal augmentation of energy is out of line with the aim of global decarbonisation. 


\section{INDONESIA'S NEW \& RENEWABLE ENERGY TARGET}

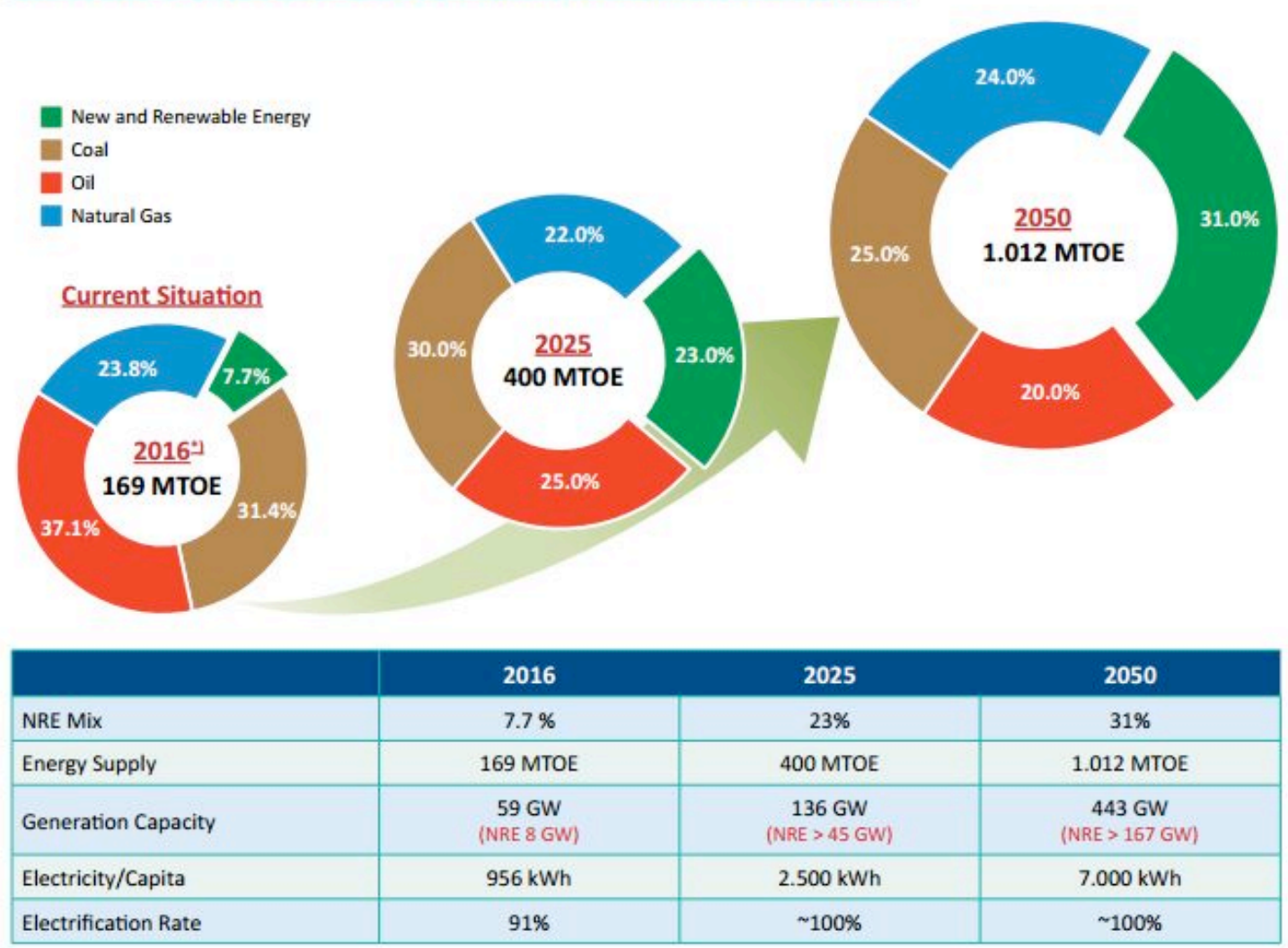

FIGURE 11. Energy future for Indonesia

USA

The US has reduced its $\mathrm{CO} 2$ emissions during the lats years, mainly by a shift to natural gas. Actually, several mature economies have been able to halt the rise of $\mathrm{CO} 2$ emissions, either by more energy efficiency or a shift to natural gas or renewables. Figure 12 captures some features in US energy plans.
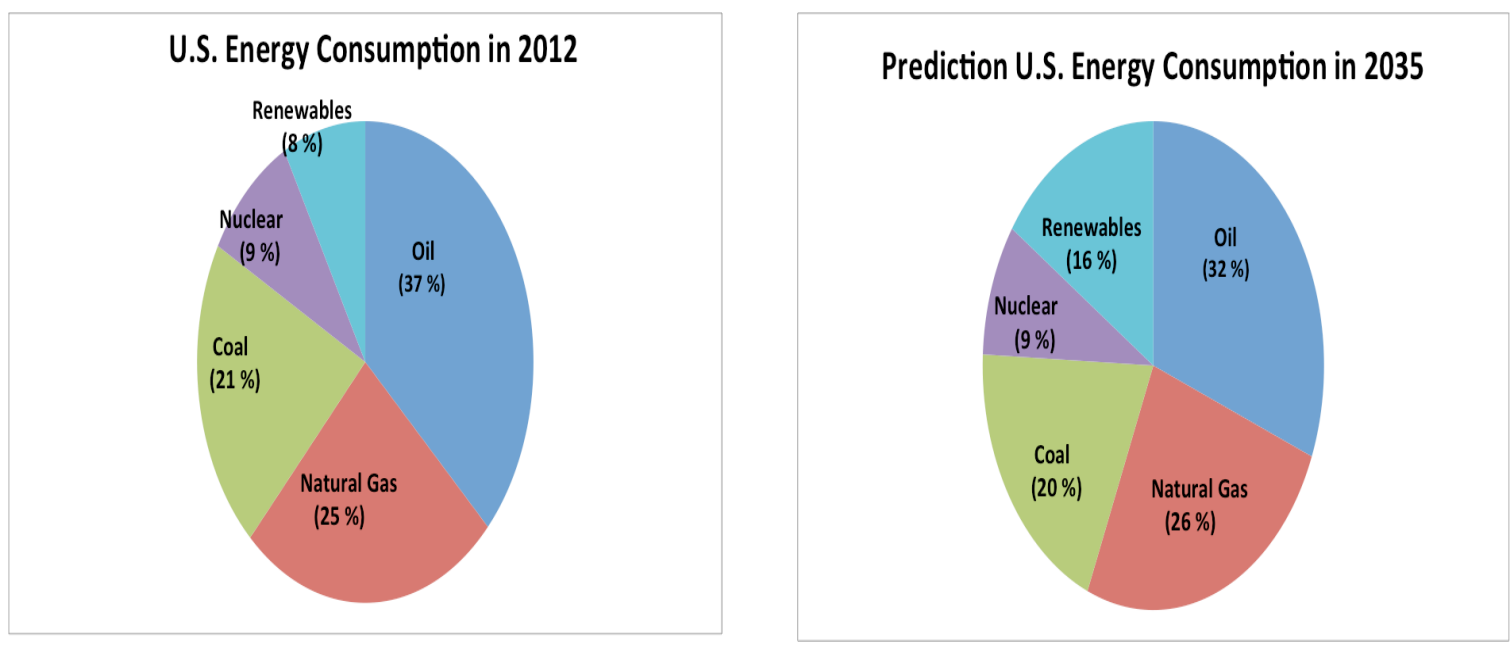

FIGURE 12. US energy future

Source: https://www.e-education.psu.edu/egee102/node/1930 
Although the Figure 12 predicts a doubling of renewable energy, the dependency upon fossil fuels, including coal energy, will not bee much reduced. We are talking here about relative numbers, but if the US increases total amount of energy supply - fracking!, then there may even be more fossil fuels. The reduction in $\mathrm{CO} 2 \mathrm{~s}$ during recent years seems to be coming at a reduced rate. The hope is for economic growth without energy increases, but we are not there yet. And most countries demand more energy for the future.

\section{China}

China now enters the First World, as it has long passed its "take-off" point in time around 1980 and has pursued a successful "catch-up" policy for a few decades. Its energy consumption, especially fossil fuels, has skyrocketed with GDP, resulting in the largest CO2 emission globally. Figure 13 has a projection for China.

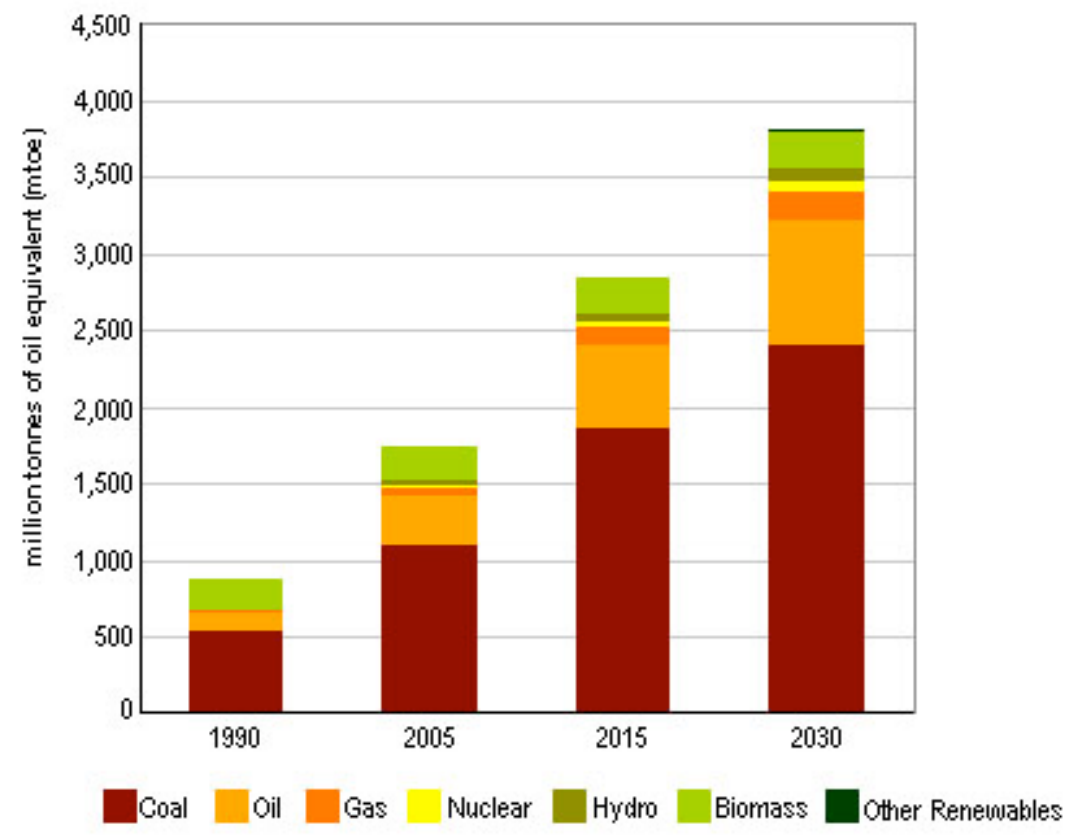

FIGURE 13. Energy projection for China

http://www.wrsc.org/attach_image/chinas-projected-energy-growth-fuel

Decarbonisation does not seem highly probable. Much hope was placed at a recent reduction in CO2s, but water shortages forced China to revert to coal in 2017 with attending augmentation of CO2s. China is investing in both renewables and atomic power, but it also plans for large energy increase in the coming decades with lots of energy consuming new projects.

\section{POLICY RESPONSES TO ABRUPT CLIMATE CHANGE}

As the potentially huge methane emissions enter the climate change debate, one fully understands the mounting pessimism. And the entire time scale for fighting global warming shrnks considerably, from 100 years to 50 years or even less. 
Yet, only improved COP21 policy-making could help. The Keeling must be stabilised as soon as possible, having reached 412 recently. The release of methane depends upon that. Thus, one may outline a more radical COP21 policy and ask for its implementation to start now:

1) Close down of all coal power plants in 2020; replacement of charcoal in poor countries by mini gas stoves;

2) Massive investments in solar power parks - see below; subsidies for solar installations in private homes;

3) Accelerated experiments with carbon capture to find accurate cost-benefit calculation for all forms of geo-enginering.

Here comes the solar power revolution that will allow a massive reduction in fossil fuels. Let us see what it entails in terms of management tasks for global coordination, assisted by for instance the COP21 Secretariat and the IPCC.

Table 1. Number of Ouarzazate plants for 40 per cent reduction of $\mathrm{CO} 2$ in some giant countries (Note: Average of 250 - $\mathbf{3 0 0}$ days of sunshine used for all entries except Australia, Indonesia, and Mexico, where 300 - 350 was used).

\begin{tabular}{|c|c|c|c|}
\hline Nation & $\begin{array}{l}\text { Co2 reduction pledge } \\
/ \% \text { of } 2005 \text { emissions }\end{array}$ & $\begin{array}{l}\text { Number of gigantic } \\
\text { solar plants needed } \\
\text { (Ouarzazate) }\end{array}$ & $\begin{array}{l}\text { Gigantic plants } \\
\text { needed for } 40 \% \\
\text { reduction }\end{array}$ \\
\hline United States & $26-28^{i}$ & 2100 & 3200 \\
\hline China & noneii & 0 & 3300 \\
\hline EU28 & $41-42$ & 2300 & 2300 \\
\hline India & none $e^{\mathrm{ii}}$ & 0 & 600 \\
\hline Japan & 26 & 460 & 700 \\
\hline Brazil & 43 & 180 & 170 \\
\hline Indonesia & 29 & 120 & 170 \\
\hline Australia & $26-28$ & 130 & 190 \\
\hline Russia & none ${ }^{\mathrm{iii}}$ & 0 & 940 \\
\hline World & N/A & $\mathrm{N} / \mathrm{A}$ & 16000 \\
\hline & & & \\
\hline
\end{tabular}

Note:i)The United States has pulled out of the deal; ii) No absolute target; iii) Pledge is above current level, no reduction; iv) Upper limit dependent on receiving financial support; v) EU joint pledge of $40 \%$ compared to 1990.

It will of course be argued against such a 40 per cent speedy reuction in $\mathrm{CO} 2 \mathrm{~s}$ that it leads to economic recession. So may it be! But it would reduce future much higher costs. After all, economies adapt and will recover due to all new investments needed in a decarbonised world. Ramesh (2015) emphasizes that India needs much eonomic assistance for decarbonisation - a giant task for global coordination to assist poor nations!

Let us look at the American scene in Table 2. 
Table 2. Number of Ouarzazate plants necessary for 40 per cent reduction in $\mathrm{CO} 2$ (Note: Average of 250 - 300 days of sunshine per year was used for Canada, 300 - 350 for the others).

\begin{tabular}{|l|c|c|c|}
\hline Nation & $\begin{array}{c}\text { Co2 reduction pledge } \\
/\end{array}$ & $\begin{array}{c}\text { Number of gigantic } \\
\text { solar plants needed } \\
\text { (Ouarzazate) }\end{array}$ & $\begin{array}{c}\text { Gigantic plants } \\
\text { needed for } \mathbf{4 0} \% \\
\text { reduction }\end{array}$ \\
\hline Canada & 30 & 230 & 300 \\
\hline Mexico & 25 & 120 & 200 \\
\hline Argentina & none $\mathrm{e}^{\mathrm{ii}}$ & 0 & 80 \\
\hline Peru & none $\mathrm{e}^{\mathrm{ii}}$ & 0 & 15 \\
\hline Uruguay & none $\mathrm{e}^{\mathrm{ii}}$ & 0 & 3 \\
\hline Chile & 35 & 25 & 30 \\
\hline
\end{tabular}

Some Latin American countries have lots of hydro power, but it may dwindle rapidly due to abrupt climate change. Solar power would be excellent energy for Mexico and Brazil for example.

Table 3 has the data for the African scene with a few key countries, poor or medium income. As they are not in general energy consuming on a grand scale, like Asia, decarbonisation should be feasible with Super Fund support.

Table 3. Number of Ouarzazate plants necessary in 2030 for 40 per cent reduction in $\mathrm{CO} 2$ (Note: Average of $\mathbf{3 0 0}$ - $\mathbf{3 5 0}$ days of sunshine per year was used).

\begin{tabular}{|l|c|c|c|}
\hline Nation & $\begin{array}{c}\text { Co2 reduction pledge } \\
/\end{array}$ & $\begin{array}{c}\text { Number of gigantic } \\
\text { solar plants needed } \\
\text { (Ouarzazate) }\end{array}$ & $\begin{array}{c}\text { Gigantic plants } \\
\text { needed for 40 \% } \\
\text { reduction }\end{array}$ \\
\hline Algeria & $7-22^{\mathrm{iv}}$ & 8 & 50 \\
\hline Egypt & none $\mathrm{e}^{\mathrm{ii}}$ & 0 & 80 \\
\hline Senegal & $5-21$ & 0,3 & 3 \\
\hline Ivory Coast & $28-36^{\mathrm{iv}}$ & 2 & 3 \\
\hline Ghana & $15-45^{\mathrm{iv}}$ & 1 & 3 \\
\hline Angola & $35-50^{\mathrm{iv}}$ & 6 & 4 \\
\hline Kenya & $30^{\mathrm{iv}}$ & 3 & 2 \\
\hline Botswana & $17^{\mathrm{iv}}$ & 1 & 1 \\
\hline Zambia & $25-47^{\mathrm{iv}}$ & 0,7 & 190 \\
\hline South Africa & none & 0 & \\
\hline
\end{tabular}

Note: Note:i)The United States has pulled out of the deal; ii) No absolute target; iii) Pledge is above current level, no reduction; iv) Upper limit dependent on receiving financial support; v) EU joint pledge of $40 \%$ compared to 1990.

Table 4 shows the number of huge solar parks necessary for a few Asian countries. 
Table 4. Number of Ouarzazate plants necessary for 40 per cent reduction in CO2s. (Note: Average of 250 - 300 days of sunshine was used for Kazakhstan, 300 - 350 days of sunshine per year for the others).

\begin{tabular}{|l|c|c|c|}
\hline Nation & $\begin{array}{c}\text { Co2 reduction pledge } \\
\text { \% of 2005 emissions }\end{array}$ & $\begin{array}{c}\text { Number of gigantic } \\
\text { solar plants needed } \\
\text { (Ouarzazate) }\end{array}$ & $\begin{array}{c}\text { Gigantic plants } \\
\text { needed for 40 \% } \\
\text { reduction }\end{array}$ \\
\hline Saudi Arabia & none ${ }^{\mathrm{ii}}$ & 0 & 150 \\
\hline Iran & $4-12^{\mathrm{iv}}$ & 22 & 220 \\
\hline Kazakhstan & none & 0 & 100 \\
\hline Turkey & 21 & 60 & 120 \\
\hline Thailand & $20-25^{\mathrm{ii}}$ & 50 & 110 \\
\hline Malaysia & none & 0 & 80 \\
\hline Pakistan & none & 0 & 60 \\
\hline Bangladesh & 3,45 & 2 & 18 \\
\hline
\end{tabular}

Given the economic advances in Asia, most countries need a lot of solar power parks for decarbonisation. The COP21 management would be able to help.

Finally, we come to the European scene.

Table 5. Number of Ouarzazate plants necessary for 40 per cent reduction in CO2s (Note: Average of $\mathbf{2 5 0}$ - $\mathbf{3 0 0}$ days of sunshine per year was used)

\begin{tabular}{|l|c|c|c|}
\hline Nation & $\begin{array}{c}\text { Co2 reduction pledge } \\
/\end{array}$ & $\begin{array}{c}\text { Number of gigantic } \\
\text { \%olar plants needed } \\
\text { (Ouarzazate) }\end{array}$ & $\begin{array}{c}\text { Gigantic plants } \\
\text { needed for 40 \% } \\
\text { reduction }\end{array}$ \\
\hline Germany & $49^{\mathrm{v}}$ & 550 & 450 \\
\hline France & $37^{\mathrm{v}}$ & 210 & 220 \\
\hline Italy & $35^{\mathrm{v}}$ & 230 & 270 \\
\hline Sweden & $42^{\mathrm{v}}$ & 30 & 30 \\
\hline
\end{tabular}

Note:Note:i)The United States has pulled out of the deal; ii) No absolute target; iii) Pledge is above current level, no reduction; iv) Upper limit dependent on receiving financial support; v) EU joint pledge of $40 \%$ compared to 1990.

The turn to renewables in Europe occur at the same time as atomic power stations are going to be closed, at least in some countries. This makes solar power plants even more relevant, a coal power must be abolished, rather sooner than later.

\section{CONCLUSION}

Time has come for halting and reducing $\mathrm{CO} 2$ emissions by real implementation and not utopian dreams of a sustainable economy (Sachs, 2015). There is nothing to wait for any longer (Stern, 2015), as the COP23 must set up the promised Super Fund. No time for politicking in the UN any longer (Conca, 2015; Vogler, 2016). 
There is no one single policy approach that "WE" must take. Each government has to present its plans and specific situation to a Cop21 managing board, in collaboration with markets and financial institutions.It must be underlined that the ultimate responsibility rests will the state and their governments (Stern, 2007, 2016). It is either Hawking irreversibility or strong global cordination as response to the new abrupt climate change abut theory. - no more time for delays (Conoa, 2015; Vogler. 2016). And holistically utopian ideas (Sachs, 2015) about sustainable development must be put aside for concentration on decarbonisation. Economic coordination requires the Super Funs (Ramesh, 2015)-

\section{REFERENCES}

\section{Solar power sources}

Paris 2015: Tracking country climate pledges. Carbon Brief, https://www.carbonbrief.org/paris2015-tracking-country-climate-pledges

EDGAR v 4.3.2, European Commission, Joint Research Centre (JRC)/PBL Netherlands Environmental Assessment Agency. Emission Database for Global Atmospheric Research (EDGAR), release version 4.3.2. http://edgar.jrc.ec.europe.eu, 2016 forthcoming

CO2 Emission Reduction With Solar

http://www.solarmango.com/in/tools/solar-carbon-emission-reduction

\section{GDP sources:}

World Bank national accounts data - data.worldbank.org

OECD National Accounts data files

\section{GHG and energy sources:}

World Resources Institute CAIT Climate Data Explorer - cait.wri.org

EU Joint Research Centre Emission Database for Global Atmospheric

Research - http://edgar.jrc.ec.europa.eu/overview.php

UN Framework Convention on Climate Change -

http://unfccc.int/ghg_data/ghg_data_unfccc/time_series_annex_i/items/3814.php

International Energy Agency. Paris.

Energy Information Administration. Washington, DC.

BP Energy Outlook 2016.

EU Emissions Database for Global Research EDGAR,

http://edgar.jrc.ec.europa.eu/ 
Jan-Erik Lane, 2018, Vol.2, Issue.5, pp.1-19

World Bank Data Indicators, data.worldbank.org

British Petroleum Statistical Review of World Energy 2016.

Environmental Performance Index, Yale University, https://epi.envirocenter.yale. IEA Statistics @ OECD/IEA 2014 (http://www.iea.org/stats/inde

\section{Literature}

Conka, K. (2015) Un Unfinished Foundation. The United Nations and Global Environmental Governance. Oxford: OUP.

Ramesh, J. (2015) Green Signals: Ecology, Growth and Democracy in India (2015). Oxford : Oxford University Press.

Sachs, J.D. (2015) The Age of Sustainable Development. New York: Columbia University Press.

Stern, N. (2007) The Economics of Climate Change. Oxford: OUP.

Stern, N. (2015) What are we waiting for? Cambridge, MA: MIT Press.

Vogler, J. (2016) Climate Change in World Politics. Basingstoke: MacmillanPalgrave

i The United States has pulled out of the deal

ii No absolute target

iii Pledge is above current level, no reduction

iv Upper limit dependent on receiving financial support

$\mathrm{V} \quad$ EU joint pledge of $40 \%$ compared to 1990 